\title{
ADSORPTION OF PARACETAMOL ON ACTIVATED CHARCOAL
}

\author{
Syed Saeed-ul-Hassan ${ }^{1 *}$, Khalid Hussain ${ }^{1}$, Syed Atif Raza ${ }^{2}$ and Nisar-ur-Rehman ${ }^{3}$ \\ ${ }^{1}$ Department of Pharmaceutical Chemistry, Faculty of Pharmacy, Punjab University, Allama \\ Iqbal Campus, Lahore-54000, Pakistan \\ ${ }^{2}$ Department of Pharmaceutic, Faculty of Pharmacy, Punjab University, Allama Iqbal \\ Campus, Lahore-54000, Pakistan \\ ${ }^{3}$ Department of Pharmacy, Islamia University, Bahawalpur, Pakistan
}

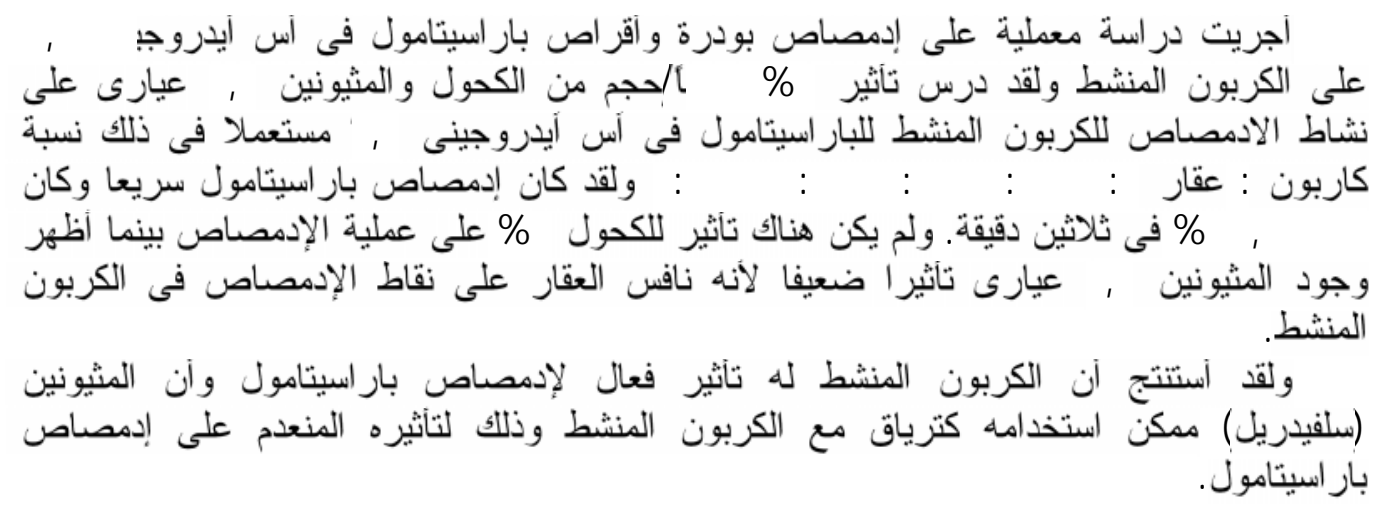

In Vitro studies were carried out to investigate the adsorption activity of activated charcoal for paracetamol powder and tablets at $p H$ 7.5. The effect of alcohol $6 \%(v / v)$ and methionine $0.1(\mathrm{M})$ on the adsorption activity of activated charcoal for paracetamol was also investigated at pH 7.5 using charcoal to drug ratios as 4:1, 5:1, 6:1, 8:1, 10:1. The adsorption of paracetamol is fast and is $95.6 \%$ in 30 minutes. There was no effect on adsorption due to presence of alcohol $6 \%$ while methionine 0.1M has little effect on the adsorption of paracetamol as methionine competes for binding sites.

It is concluded that activated charcoal is effective in adsorbing paracetamol. Methionine (sulphydryl) compound can be used as an antidote along with activated charcoal because of its negligible effect on adsorption of paracetamol.

\section{INTRODUCTION}

The First systemic studies of charcoal as an antidote were performed in early 18th century. Tourey, a French pharmacist explained his findings for French Academy of Medicine. During the following hundred years, several studies on the activated charcoal were published, ${ }^{1}$ but its use as an antidote was not accepted. The activated charcoal was not available as a recognized drug in USA and commercial preparation of charcoal usually specified that it was not to be used in human subjects. ${ }^{1}$ After qualitative studies on the effect of adequate doses of charcoal both on absorption and elimination of drugs have been performed, as a result activated charcoal was rediscovered in treating intoxications.

Activated charcoal is a fine black insoluble powder having no taste. After pyrolysis of organic matter (Wood pulp), the charcoal is activated by an oxidizing gas flow at high temperature to make a fine network of pores. As it absorbs gas from air, therefore it should be protected to prevent the loss of potency. ${ }^{2}$

Activated charcoal can be given as suspension. For optimum results finely powdered activated charcoal should be used. The efficacy of coated charcoal tablet is inferior to powdered charcoal tablets when studied In Vitro and In Vivo. ${ }^{3}$ 
Paracetamol has analgesic and antipyretic properties. It is given by oral or as per rectal for mild to moderate pain and pyrexia and indeed is much safer than aspirin. ${ }^{4}$ The severe and fatal liver damage following overdose of paracetamol was first reported from Scotland. . $^{5-6}$ Similar reports came from other countries. ${ }^{7-9}$ Nausea, vomiting and abdominal pain usually occur within a few hour of ingestion of a hepatotoxic dose of paracetamol followed by hepatic tenderness. Mild jaundice may became apparent followed by rapid and complete recovery. ${ }^{10}$ The onset of back pain is due to development of oliguric renal failure. ${ }^{11-15}$ Other complications observed are metabolic acidosis, pancreatitis and cardiac toxicity. ${ }^{16-18}$

Paracetamol is metabolized in liver and excreted through kidney mainly as glucouronide and sulphate conjugates. The metabolism of other drugs is also impaired in patients with liver damage following paracetamol overdosage.

The biochemical mechanism of paracetamol hepatotoxicity was first described by Mitchell and his colleagues. ${ }^{19-21}$

Maximum single therapeutic doses of paracetamol do not produce liver toxicity in man and, although the threshold dose has been estimated as 10 to $15 \mathrm{~g}$. Unfortunately, no reliance can be placed on the dose claimed to have been taken by the patient and unknown amount may be lost by gastric lavage and vomiting. However, the amount absorbed can be estimated as the product of plasma paracetamol concentration three hour after ingestion and apparent volume of distribution $\left(0.8 \mathrm{LKg}^{-1}\right)$. On this basis the threshold dose in man appears to be $250 \mathrm{mg} \mathrm{Kg}^{-1}$ body weight. All patients who absorb more than $250 \mathrm{mg} \mathrm{Kg}^{-1}$ body weight had severe liver damage. ${ }^{22}$

Paracetamol is often recommended instead of aspirin for alcoholic patients who have high incidence of G.I. bleeding. However chronic ethanol consumption induces hepatic cytochrome $\mathrm{p}-450{ }^{23}$ and depeletes hepatic glutathione and rises the possibility of a potential toxic interaction between paracetamol and ethanol. This statement was also confirmed by the work of Peterson F.J. ${ }^{24}$

Several sulphydryl compounds are used as antidotes which protect the effect of paracetamol metabolite that causes depletion of hepatic glutathione. Activated charcoal may adsorb antidote and reduces its bioavailability in treatment of paracetamol poisoning. The present study was performed using sulphydryl compound (methionine) to find out any effect of charcoal on its bioavailability. For the treatment of over dose of paracetamol activated charcoal may be used to reduce the bioavailabilty of paracetamol due to its adsorption on activated charcoal.

\section{MATERIALS AND METHODS}

The following materials which were of analytical grade were used, paracetamol, sodium hydroxide, monobasic potassium phosphate, distilled water and Carbomix (activated charcoal). Whatman filter papers and paracetamol tablets $500 \mathrm{mg}$, B.P, (Rickett \& Colman) were also used. $\mathrm{pH}$ meter, UV/ visible spectrophotometer (Model 2000), weighing balance (Petit Balance Ohyo Balance Corporation, Japan) were the equipment used.

\section{Preparation of sodium hydroxide solution}

Sodium hydroxide solution $0.2 \mathrm{M}$ was prepared by dissolving $8 \mathrm{gm}$ of sodium hydroxide per liter of distilled water.

\section{Vehicle preparation for adsorption studies}

Simulated intestinal fluid (SIF) was prepared in accordance with the method described in the $\mathrm{USP}^{25}$ except the enzyme pancreatin was omitted in this study.

Monobasic potassium phosphate 34.0022 $\mathrm{g}$ was taken in 5 liter volumetric flask and mixed with $1.250 \mathrm{ml}$ of water, $950 \mathrm{ml}$ of $0.2 \mathrm{M}$ sodium hydroxide and 2 liter of water were added and the resulting solution was adjusted to $\mathrm{pH} 7.5 \pm 0.1$ with $0.2 \mathrm{M} \mathrm{NaOH}$. The volume was made up to 5 liter with distilled water.

\section{Preparation of calibration graph}

A graph of known concentrations verses absorbance was plotted and then concentration of the unknown solution was found by using the calibration graph of absorbance and concentration at $257 \mathrm{~nm}$.

Paracetamol $0.1 \mathrm{~g}$ of powder was taken in $100 \mathrm{ml}$ volumetric flask. It was first dissolved with SIF to make the volume. Ten $\mathrm{ml}$ of this solution was transferred to $100 \mathrm{ml}$ volumetric flask and diluted to $100 \mathrm{ml}$ with SIF. Similarly further dilutions were made. The data of 
calibration graph is mentioned in Table 1 and Fig 1.

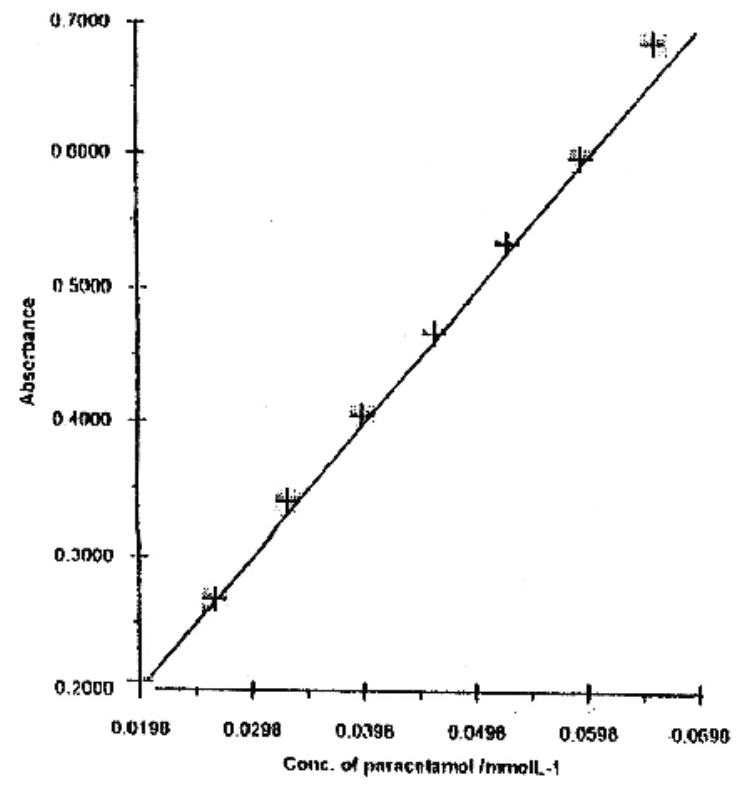

Fig. 1: Calibration curve of paracetamol in SIF (pH 7.5).

\section{Determination of Equilibrium Contact Time}

Equivalent to $1.512 \mathrm{~g}$ of paracetamol was transferred into $500 \mathrm{ml}$ volumetric flask and dissolved in SIF and made up the volume with SIF. Aliquots of $25 \mathrm{ml}$ of paracetamol solution ( $0.5 \mathrm{mmol}$ of paracetamol) were pippetted into six stoppered tube containing $0.3024 \mathrm{~g}$ of activated charcoal (charcoal to drug ratio 4:1). A sample was removed at 5, 10, 15, 30, 45 and 60 minutes intervals. The samples were filtered and analyzed at $257 \mathrm{~nm}$ using SIF as blank.
Paracetamol adsorption on different concentrations of activated charcoal at pH 7.5

Aaliquots of $25 \mathrm{ml}$ of paracetamol solution were placed in glass tubes containing $0.30,0.38,0.45,0.60$ and $7.5 \mathrm{~g}$ of activated charcoal. The mixtures were filtered and absorbance was measured at $257 \mathrm{~nm}$ using SIF with charcoal.

Determination of adsorption of Paracetamol tablets on different concentrations of activated Charcoal at pH 7.5

- Each tablet contains paracetamol $=500 \mathrm{mg}$

- Weight of 20 paracetamol tablets $=11.933 \mathrm{~g}$

- Weight of one paracetamol tablet $=0.5966 \mathrm{~g}$

20 tablets were weighed and powdered and $0.1779 \mathrm{~g}$ powder of paracetamol (equivalent to $0.150 \mathrm{~g}$ ) was taken in $200 \mathrm{ml}$ volumetric flask. $50 \mathrm{ml}$ of $0.1 \mathrm{M} \mathrm{NaOH}$ was transferred to the flask and diluted with $100 \mathrm{ml}$ of water and volume was made to $200 \mathrm{ml}$. 10 $\mathrm{ml}$ of solution was diluted to $100 \mathrm{ml}$. From this $10 \mathrm{ml}$ solution was further diluted to $100 \mathrm{ml}$ with $0.1 \mathrm{M} \mathrm{NaOH}$. The absorbance was measured at $257 \mathrm{~nm}$.

\section{RESULTS AND DISCUSSION}

The results of the studies on adsorption of Paracetamol powder on activated charcoal were presented in Table 2. It is clear from the table that adsorption of paracetamol was $95.6 \%$ within 30 minutes. Adsorption was completed within 45 minutes.

Table 1: Standard curve for determination of paracetamol.

\begin{tabular}{|c|c|c|c|c|c|c|c|}
\hline \hline S.S & F.V & Conc./m & \multicolumn{5}{|c|}{ ABSORBANCE } \\
\cline { 4 - 8 } $\mathrm{ml}$ & $\mathrm{Ml}$ & $\mathrm{Ml}^{-1}$ & 1 & 2 & 3 & 4 & Mean \\
\hline 10 & 100 & 0.661 & 0.669 & 0.689 & 0.689 & 0.686 & 0.686 \\
\hline 9 & 100 & 0.0595 & 0.599 & 0.606 & 0.588 & 0.600 & 0.598 \\
\hline 8 & 100 & 0.0529 & 0.540 & 0.532 & 0.525 & 0.534 & 0.533 \\
\hline 7 & 100 & 0.0463 & 0.467 & 0.473 & 0.461 & 0.467 & 0.467 \\
\hline 6 & 100 & 0.0397 & 0.401 & 0.409 & 0.403 & 0.403 & 0.404 \\
\hline 5 & 100 & 0.0331 & 0.333 & 0.343 & 0.347 & 0.341 & 0.341 \\
\hline 4 & 100 & .0265 & 0.265 & 0.270 & 0.269 & 0.269 & 0.268 \\
\hline 3 & 100 & 0.198 & 0.203 & 0.210 & 0.205 & 0.205 & 0.206 \\
\hline
\end{tabular}

S.S = Standard solution F.V = Full Volume 
Table 2: Amount of paracetamol adsorbed at different time intervals.

\begin{tabular}{|c|c|c|c|c|c|c|c|c|c|c|}
\hline \multirow{2}{*}{ T/Min } & \multicolumn{4}{|c|}{ Absorbance } & \multirow{2}{*}{$\begin{array}{l}\mathrm{C} / \mathrm{X} 10^{2} \\
\mathrm{mmol} / \mathrm{L}\end{array}$} & \multirow{2}{*}{$\begin{array}{c}\text { Dilution } \\
\text { Factor } \\
\end{array}$} & \multirow{2}{*}{$\begin{array}{c}\mathrm{Ceq} / \\
\mathrm{mmol} / \mathrm{L}\end{array}$} & \multirow{2}{*}{$\begin{array}{c}\mathrm{Ceq} / \\
\mathrm{mmol} / 25 \mathrm{ml}\end{array}$} & \multirow{2}{*}{$\begin{array}{c}\mathrm{X} / \\
\mathrm{mmol}\end{array}$} & \multirow{2}{*}{$\begin{array}{c}\% \\
\text { Adsorbed }\end{array}$} \\
\hline & 1 & 2 & 3 & Mean & & & & & & \\
\hline 5 & 0.309 & 0.309 & 0.311 & 0.310 & 30.420 & 1 in 100 & 3.0420 & 0.0760 & 0.4240 & 48.8 \\
\hline 10 & 0.195 & 0.193 & 0.197 & 0.196 & 1.9219 & 1 in 100 & 1.9219 & 0.0480 & 0.4520 & 90.4 \\
\hline 15 & 0.300 & 0.304 & 0.301 & 0.302 & 2.9635 & 50 & 1.4818 & & 0.4630 & 92.6 \\
\hline 30 & 0.178 & 0.176 & 0.130 & 0.178 & 1.7450 & 1 in 50 & 0.8725 & 0.0218 & 0.4782 & 95.6 \\
\hline 45 & 0.130 & 0.129 & 0.177 & 0.130 & 1.2733 & 1 in 50 & 0.6366 & 0.0159 & 0.4841 & 96.8 \\
\hline 60 & 0.643 & 0.646 & 0.646 & 0.646 & 6.3492 & 1 in 10 & 0.6349 & 0.0159 & 0.4841 & 96.8 \\
\hline
\end{tabular}

$\mathrm{T}=$ Time

$\mathrm{C}=$ Concentration

$\mathrm{X}=$ Amount of paracetamol adsorbed
$\mathrm{Ceq}=$ Equilibrium concentration
The findings of the investigations on adsorption of paracetamol on activated charcoal with various charcoal to drug proportions are given in Table 3. The adsorption was almost complete at 5:1 charcoal drug ratio and is $98.86 \%$. There is increase in adsorption with the increase in concentration of charcoal, but the percentage adsorption was negligible as compared to increase in concentration of charcoal. The data for the adsorption of paracetamol for tablets is given in Table 4. The decrease in adsorption may be due to adsorption of the drug to tablet inactive ingredients. The blank was only SIF. The ideal blank should contain all ingredients which are present in tablets except paracetamol.

The effect of alcohol $(6 \% \mathrm{v} / \mathrm{v})$ on paracetamol adsorption is shown in Table 5. It was found that alcohol has no effect on the adsorption of paracetamol on activated charcoal. Beside other physiological properties molecular weight of alcohol and paracetamol (46 and 151.2). The molecular size of alcohol is one third the size of paracetamol, therefore alcohol is very less likely to have any effect on the adsorption of paracetamol onto activated charcoal. Patients with history of alcoholism may have increased susceptibility to paracetamol induced toxicity. Paracetamol is metabolized predominatly in the liver and is excreted mainly as glucuronide and sulphate conjugates which are very polar and are ionized at $\mathrm{pH}$ of blood and urine and are excreted easily. The combination of paracetamol with glucuronic acid occurs readily with compounds having reactive proton, usually attached to hetro atom (hydroxyl, carboxylic, amino and sulfhydryl).
The adsorption results of paracetamol in the presence of $0.01 \mathrm{M}$ methionine using SIF of $\mathrm{pH} 7.5$ and using charcoal to drug ratio between 4:1 and 10:1 are given in Table 6 . There is reduction of paracetamol adsorption in presence of methionine. Beside other physiochemical properties there is similarity in size of Paracetamol and methionine which play role in competing for adsorption sites on activated charcoal.

Since the adsorption of paracetamol on activated charcoal is only reduced by $8 \%$ in the presence of methionine, charcoal can be used in removing paracetamol molecules, while at the same time only slightly reducing the bioavailability of metionine. Hepatotoxicity is related to the conversion of a small fraction of the dose to a highly reactive alkylating metabolite which is normally inactivated by preferential conjugation with glutathione and eventually excreted as cystine and mercapturic acid conjugates. Liver damage is associated with glutathione depletion, and this compound would seem to be an ideal antidote. Unfortunately, glutathione itself does not enter cells readily and it is ineffective in preventing experimental paracetamol hepatotoxicity. In contrast, glutathione precursors and related compounds such as cysteine, $\mathrm{N}$-acetylcysteine, cysteamine and methione have been studied clinically in paracetamol poisoning. They prevent covalent binding and hepatic necrosis in animals and have been remarkably successful in preventing liver damage following paracetamol overdosage in man. 
Table 3: Adsorption studies of paracetamol on activated charcoal.

\begin{tabular}{|c|c|c|c|c|c|c|c|c|c|c|c|c|c|c|c|}
\hline \multirow{2}{*}{$\mathrm{m} / \mathrm{g}$} & \multirow{2}{*}{$\begin{array}{l}\text { Drug } \\
\text { Ratio }\end{array}$} & \multirow{2}{*}{$\begin{array}{c}\text { Amount } \\
\text { Used/g }\end{array}$} & \multicolumn{4}{|c|}{ ABSORBANCE } & \multirow{2}{*}{$\begin{array}{l}\mathrm{C} / \mathrm{X} 10^{-2} \\
\mathrm{mmol} / \mathrm{L}\end{array}$} & \multirow{2}{*}{$\begin{array}{l}\text { Dilution } \\
\text { factor }\end{array}$} & \multirow{2}{*}{$\begin{array}{c}\text { Ceq/ } \\
\mathrm{mmol} / \mathrm{L}\end{array}$} & \multirow{2}{*}{$\begin{array}{l}\mathrm{Ceq} / \mathrm{x} 10^{-2} \\
\mathrm{mmol} / 25 \mathrm{ml}\end{array}$} & \multirow{2}{*}{$\mathrm{X} / \mathrm{mmol}$} & \multirow{2}{*}{$\mathrm{X} / \mathrm{mg}$} & \multirow{2}{*}{$\begin{array}{c}\mathrm{X} / \mathrm{m} \\
\mathrm{mmol} / \mathrm{g}\end{array}$} & \multirow{2}{*}{$\begin{array}{l}\mathrm{Ceq} / \mathrm{X} / \mathrm{m} \\
\text { Per g per L }\end{array}$} & \multirow{2}{*}{$\begin{array}{c}\% \\
\text { Adsorbec }\end{array}$} \\
\hline & & & 1 & 2 & 3 & Mean & & & & & & & & & \\
\hline 0.30 & $4: 1$ & 0.3001 & 0.304 & 0.317 & 0.291 & 0.302 & 2.9635 & 1 in 20 & 0.5927 & 1.4818 & 0.4852 & 73.362 & 1.6168 & 0.3666 & 97.06 \\
\hline 0.38 & $5: 1$ & 0.3810 & 0.508 & 0.429 & 0.439 & 0.462 & 4.5358 & 1 in 5 & 0.2268 & 0.5670 & 0.4943 & 74.738 & 1.2974 & 0.1748 & 98.86 \\
\hline 0.45 & $6: 1$ & 0.4488 & 0.783 & 0.733 & 0.785 & 0.775 & 7.6116 & 1 in 2 & 0.1522 & 0.3805 & 0.04962 & 75.025 & 1.1059 & 0.1377 & 99.24 \\
\hline 0.60 & $8: 1$ & 0.6035 & 0.700 & 0.708 & 0.730 & 0.705 & 6.9237 & None & 0.0692 & 0.1730 & 0.4983 & 75.343 & 0.8257 & 0.0838 & 99.66 \\
\hline 0.75 & $10: 1$ & 0.7530 & 0.505 & 0.575 & 0.564 & 0.541 & 5.3121 & none & 0.0531 & 0.1328 & 0.4987 & 75.403 & 0.6623 & 0.0802 & 99.74 \\
\hline
\end{tabular}

$\mathrm{M}=$ amount of charcoa

$\mathrm{C}=$ Concentration obtained from calibration graph

Ceq = Equilibrium concentrations

Table 4: Adsorption studies of paracetamol tablets on activated charcoal.

\begin{tabular}{||c|c|c|c|c|c|c|c|c|c|c|c|c|c||}
\hline $\mathrm{m} / \mathrm{g}$ & $\begin{array}{c}\text { Drug } \\
\text { ratio }\end{array}$ & $\begin{array}{c}\text { Amount } \\
\text { used/g }\end{array}$ & Absorbance & $\begin{array}{c}\mathrm{C} / \\
\mathrm{mmol} / \mathrm{L}\end{array}$ & $\begin{array}{c}\text { Dilution } \\
\text { Factor }\end{array}$ & $\begin{array}{c}\mathrm{Ceq} / \\
\mathrm{mmol} / \mathrm{L}\end{array}$ & $\begin{array}{c}\mathrm{Ceq} / \\
\mathrm{Mmol} / \mathrm{L}\end{array}$ & $\begin{array}{c}\mathrm{Ceq} / \mathrm{x} 10^{-2} \\
\mathrm{mmol} / 25 \mathrm{ml}\end{array}$ & $\begin{array}{c}\mathrm{X} / \\
\mathrm{mmol}\end{array}$ & $\begin{array}{c}\mathrm{X} / \mathrm{mg} \\
\text { adsorbed }\end{array}$ & $\begin{array}{c}\mathrm{X} / \mathrm{m} \\
\mathrm{mmol} / \mathrm{g}\end{array}$ & $\begin{array}{c}\mathrm{Ceq} / \mathrm{x} / \mathrm{m} / \\
\mathrm{g} / \mathrm{L}\end{array}$ \\
\hline 0.30 & $4: 1$ & 0.3051 & 0.341 & 3.3467 & 1 in 50 & 1.6734 & 1.6734 & 4.1834 & 0.4581 & 69.26 & 91.62 & 1.5017 & 1.1140 \\
\hline 0.38 & $5: 1$ & 0.3772 & 0.300 & 2.9439 & 1 in 50 & 1.4719 & 1.4719 & 3.6799 & 0.4632 & 70.04 & 92.64 & 1.2279 & 1.1986 \\
\hline 0.45 & $6: 1$ & 0.4551 & 0.115 & 1.1259 & 1 in 25 & 0.2815 & 0.2815 & 0.7037 & 0.4930 & 74054 & 98.6 & 1.0832 & 0.2599 \\
\hline 0.60 & $8: 1$ & 0.6401 & 0.259 & 2.5410 & 1 in 5 & 0.1270 & 0.1270 & 0.3176 & 0.4968 & 75.15 & 99.36 & 0.8224 & 0.1644 \\
\hline 0.75 & $10: 1$ & 0.7552 & 0.190 & 1.8629 & 1 in 5 & 0.0931 & 0.0931 & 0.2329 & 0.4977 & 75.25 & 99.54. & 0.6590 & 0.1413 \\
\hline
\end{tabular}

$\mathrm{M}=$ amount of charcoal $\quad \mathrm{C}=$ Concentration obtained from calibration graph $\quad$ Ceq = Equilibrium concentrations 
Table 5: Adsorption studies of paracetamol in presence of alcohol $6 \% \mathrm{v} / \mathrm{v}$ with different drug to charcoal ratios.

\begin{tabular}{|l|l|c|c|c|c|c|c|c|}
\hline $\begin{array}{l}\text { Amount } \\
\text { used/g }\end{array}$ & Absorbance & $\begin{array}{c}\text { Dilution } \\
\text { Factor }\end{array}$ & $\begin{array}{c}\mathrm{Ceq} / \\
\mathrm{mmol} / \mathrm{L}\end{array}$ & $\mathrm{X} / \mathrm{mmol}$ & $\mathrm{X} / \mathrm{mg}$ & $\begin{array}{c}\% \\
\text { Adsorbed }\end{array}$ & $\begin{array}{c}\mathrm{X} / \mathrm{m} \\
\mathrm{mmol} / \mathrm{g}\end{array}$ & $\mathrm{Ceq} / \mathrm{x} / \mathrm{m} / \mathrm{g} / \mathrm{L}$ \\
\hline 0.3021 & 0.481 & 1 in 10 & 0.471 & 0.488 & 73.78 & 97.60 & 1.615 & 0.292 \\
\hline 0.3778 & 0.424 & 1 in 5 & 0.208 & 0.495 & 74.84 & 99.99 & 1.310 & 0.178 \\
\hline 0.4541 & 0.666 & 1 in 2 & 0.131 & 0.497 & 75.15 & 99.40 & 1.094 & 0.119 \\
\hline 0.6051 & 0.681 & None & 0.067 & 0.498 & 75.30 & 99.60 & 0.823 & 0.081 \\
\hline 0.7565 & 0.407 & none & 0.040 & 0.499 & 75.45 & 99.80 & 0.660 & 0.061 \\
\hline
\end{tabular}

Table 6: Adsorption of paracetamol in the presence of methionine $(0.1 \mathrm{M})$.

\begin{tabular}{|c|c|c|c|c|c|c|c|c|}
\hline $\begin{array}{c}\text { Amount } \\
\text { used/g }\end{array}$ & Absorbance & $\begin{array}{c}\text { Dilution } \\
\text { factor }\end{array}$ & $\begin{array}{c}\text { Ceq/ } \\
\mathrm{mmol} / \mathrm{L}\end{array}$ & $\begin{array}{c}\mathrm{X} / \mathrm{mm} \\
\mathrm{ol}\end{array}$ & $\mathrm{X} / \mathrm{mg}$ & $\begin{array}{c}\% \\
\text { Adsorbed }\end{array}$ & $\begin{array}{c}\mathrm{X} / \mathrm{m} \\
\mathrm{mmol} / \mathrm{g}\end{array}$ & Ceq/x/m/g/L \\
\hline 0.3034 & 0.239 & 1 in 25 & 0.583 & 0.485 & 73.33 & 97.00 & 1.599 & 0.365 \\
\hline 0.3789 & 0.637 & 1 in 15 & 0.321 & 0.493 & 74.54 & 98.60 & 1.301 & 0.270 \\
\hline 0.4558 & 0.146 & 1 in 10 & 0.142 & 0.496 & 75.00 & 99.20 & 1.090 & 0.130 \\
\hline 0.6078 & 0.673 & None & 0.066 & 0.498 & 75.30 & 99.60 & 0.820 & 0.008 \\
\hline 0.7581 & 0.404 & none & 0.040 & 0.499 & 75.45 & 99.80 & 0.658 & 0.006 \\
\hline
\end{tabular}

\section{REFERENCES}

1- J. W. Hayden and E. G. Comstock, Clinical Toxicology, 8, 515-533 (1975).

2- R. A. Braithwaite, et al., Br. J. Clinical Pharmacology, 5, 369 (1978).

3- T. Tsuchiya and G. Levy, J. Pharm. Sci., 61, 586-589 (1972).

4- J. E. F. Reynolds, "Martindale The Extra Pharmacopoeia", $30^{\text {th }}$ ed., Royal Pharmaceutical Society of Great Britain, 1 Lambeth High Street, London SE17 JN, U.K., 1993, pp. 839-850.

5- D. G. D. Davidson and W. N. Eastham, "Acute Liver Necrosis Following Overdose of Paracetamol", Ibid., 2, 1966, pp.497-499.

6- J. S. Thomson and L. F. Prescott, Br. Med. J., 2, 506-507 (1966).

7- D. Maclean, et al., ibid., 2, 849-852 (1968).

8- L. F. Prescott, et al., Lancet., 1, 519-522 (1971).

9- A. T. Proudfoot and N. Wright, Br. Med. J., 3, 557-558 (1970).

10- R. Clark, et al., Lancet., 1, 66-69 (1973).

11- L. F. Prescott, et al., Ibid., 2, 1399 (1978).

12- L. F. Prescott, et al., Ibid., 28, 421-22 (1982).
13- J. Can, et al., Ibid., 282, 199-201 (1981).

14- B. McJunkin, et al., J. Amer. Med. Assoc., 236, 1874-1875 (1976).

15- E. J. Eastham, et al., Br. Med. J., 1, 750751 (1976).

16- R. A. Coward, Ibid., 1, 1086 (1977).

17- I. T. Gilmor and E. Tourvas, Ibid., 1, 753754 (1977).

18- J. G. Harvey and J. B. Spooner, Ibid., 2, 832-33 (1978).

19- J. R. Mitchell, et al., J. Pharmacology and Experimental Therapeutics, 187, 185-194 (1973).

20- W. Z. Potter, et al., Ibid., 187, 203-210 (1973).

21- D. J. Jollow, et al., ibid., 187, 195-203 (1973).

22- J. Ambre and M. Alexander, J. Amer. Med. Assoc., 238, 500-501 (1977).

23- H. Kalant, et al., Biochem. Pharmac., 25, 887 (1976).

24- F. J. Peterson, et al., Life Sciences, 27, 1705-1711 (1980).

25- United States Pharmacopoeia, United States Pharmacopeial Convention Inc., 12601, Twinbrook, Parkway, Rockville, M.D., 20852, ed. 21, 1985, p.1424. 